\title{
Thermodynamic Analysis of Eco-Friendly Refrigerant Mixtures as an Alternative to HFC- 134a in Household Refrigerator
}

\author{
Mohammad Hasheer Shaik*, Srinivas Kolla, Tara Chand Vadlamudi, Bala Prasad Katuru, Ravindra Kommineni \\ Department of Mechanical Engineering, R.V.R. \& J.C. College of Engineering (A), Guntur, Andhra Pradesh 522019, India
}

Corresponding Author Email: hasheer.mohammad@gmail.com

https://doi.org/10.18280/ijht.390519

Received: 26 August 2019

Accepted: 2 July 2021

\section{Keywords:}

eco-friendly refrigerants-AC5, R440A and $R 430 A$, household refrigerator, liquid suction heat exchanger

\begin{abstract}
Nowadays, research has been focused on refrigerants from Hydrofluorocarbons (HFCs), which are not harmful to the ozone layer. Because of replacing refrigerants from chlorofluorocarbons (CFCs) and hydrochlorofluorocarbons (HCFCs). HFCs are used in many applications, including refrigerants, aerosols, solvents, and blowing agents for insulating foams. However, some HFCs have relatively high global warming potential (GWP) and are subject to further examination due to growing concerns about global climate change. The present work's main objective is to select eco-friendly refrigerants from AC5, R430A and R440A, combining two or more refrigerants from HC, HFC and HFO groups as a direct substitute HFC-134a in a household refrigerator. The performance of the domestic refrigerator with liquid suction heat exchanger (LSHX) was compared in terms of compressor discharge temperature, coefficient of performance (COP), volumetric cooling capacity (VCC), and power consumption of a compressor. It was found that the average COP of R440A and R430A was higher by approximately $2.5 \%$ and $1.47 \%$ than HFC-134a. However, the COP of AC5 was $6.1 \%$ lower than that of HFC-134a. The VCC of R430A is almost equal to HFC-134a. The results also show that AC5, R440A and R430A consume less power than HFC-134a. The compressor outlet temperature with R440A, AC5 provide higher values than HFC-134a, which affects the compressor life. The best overall performance was achieved with the refrigerant R430A in the household refrigerator and suggested an alternative to HFC134a, which also has a very low GWP from the environmental safety perspective.
\end{abstract}

\section{INTRODUCTION}

Environmental pollution is aggravated by the excessive use of refrigerators and air conditioners worldwide, along with automobiles. The ozone layer is damaged by releasing refrigerants containing chlorine into the atmosphere. Due to this, dangerous ultraviolet radiations are coming to the surface of the earth. As a result, the earth's surface temperature is increasing rapidly, leading to weather change. The effect of these greenhouse gases can be expressed in terms of GWP. In the last 30 years, CFCs and HFCs are widely used in refrigerators and air conditioners. However, ODP and GWP values are very high for these refrigerants, which cause environmental pollution. According to Montreal protocol, chlorofluorocarbons and HCFC are entirely prohibited in the air conditioning and refrigeration sector due to this higher ODP value. Therefore, in place of these refrigerants, HFC refrigerants are introduced, but the main problem with these refrigerants is that they have a higher GWP value. Therefore, these should be banned in the coming years based on the Kyoto Protocol. Therefore, R134a has to be phased out by 2021. In addition, most of the developing countries are drastically reducing their HFC production and consumption. Therefore, there is a greater demand for an adequate replacement for HFC-134a to adapt to existing and new systems.

Hoe et al. [1] experimented with R600a, which is a substitute to the R12 in a household refrigerator. They analyzed theoretically with the help of software REFPROP, and then performed a series of tests with this refrigerant substitute to R134a in a fridge. Jung et al. [2] conducted an experiment with a mixture of HC290 / HC600a (60:40 by mass) as a direct substitute for R12 in a refrigerator and concluded that COP and power efficiency improved by 2.5 and $3.8 \%$. Fatouh and Kafafy [3] studied the performance of the household refrigerator that works with the refrigerant mixture (consist of HC290 / HC600 / HC600a in the ratio 60:20:20 by mass) a substitute to HFC-134a. It has been reported that the power consumption of compressor operating with an LPG blend was $5.1 \%$ lower than HFC-134a with 7.5\% higher COP. Garland and Hadfield [4] studied the environmental impact of the R600a natural refrigerant installed in the hermetic compressor of the household refrigerator. The results showed that the R600a is superior to the R134a, with the compressor having its 15-year cycle.

Dalkilic and Wongwises [5] conducted a theoretical analysis on the refrigerator using various alternative refrigerants and refrigerant mixtures as an alternative to R12 and R22. They concluded that HFC and HC refrigerants could be used as alternatives to the above refrigerants from that theoretical analysis. Naushad et al. [6] had conducted an energy and exergy analysis of R1234yf, R1234ze (E) and $\mathrm{R} 134 \mathrm{a}$ in a domestic refrigeration system. Finally, they concluded that HFO-1234yf could be used as a good substitute for $\mathrm{HFC}-134 \mathrm{a}$ at a higher value of the evaporator temperature, and R1234ze (E) can be used as a suitable replacement after specific modification. Rastietal [7] conducted an experiment 
on R600aand R436a consisting of $46 \%$ and $50 \%$ of isobutane and propane) as an alternative to R134a in a household refrigerator. The results concluded that the compressor energy consumption and volumetric cooling capacity was reduced by about $15 \%$ and $8 \%$, respectively. Joybari et al. [8] carried out the exergy analysis to find the optimal load of HC-600a as a substitute for HFC-134a, the optimum load required for HC$600 \mathrm{a}$ was $0.050 \mathrm{kgand} 65 \%$ lower than HFC-134a. Bilen et al. [9] investigated theoretical analysis of the automobile air conditioning system using R152a, R22 and R12 to find out possible alternatives to R134a. From the results, they concluded that the performance does not change significantly by using R152a as compared with R134a. Bolaji et al. [10] made a performance comparison of low GWP refrigerants like R152a and HC600 theoretically, an alternative to HFC134a in a refrigerator. By observing these results, they concluded that R152a shows a higher volumetric cooling capacity (VCC) and co-efficient performance compared to HFC-134a. The average COPs achieved for $\mathrm{HC}-600 \mathrm{a}$ and $\mathrm{HC}-152 \mathrm{a}$ were $6 \%$ lower and $12.9 \%$ higher than HFC-134a. They concluded that HFC-152a shows the best results as compared with R134a. Morsi [11] performed a theoretical analysis of a VCR system using pure natural refrigerants to substitute HFC-134a. Results revealed that LPG gives a lower COP, and Isobutene gives a higher COP than HFC-134a by $11 \%$ and $5 \%$, respectively.

Meng et al. [12] have done thermodynamic investigation for HFO-1234ze (E), R152a and HFO-1234ze (E)/R152a blends as a direct substitute to HFC-134a in a refrigerator system without making any modifications to the system. Sanchez et al. [13] led an experiment with low GWP refrigerants like HFO-1234yf, 1234ze (E), R290, R152a and HC-600a in the refrigeration system and experimental results were compared with HFC-134a. From that experiment, they concluded that HFO-1234yf and R152a have a perfect substitute for HFC134a. Makhnatch et al. [14] examined the performance ofR450Awhich is a mixture of R134a/R1234ze (E) $(42: 58 \%$ by mass) as a substitute to HFC-134a in household refrigerators. It has been revealed that the Refrigerating effect and $\mathrm{COP}$ of the refrigerant mixture were approximately $10 \%$ and $3 \%$ lower than HFC-134a. At the same time, the outlet temperature of the compressor is more inferior to HFC-134a. Hasheer and Srinivas [15] conducted a theoretical investigation on low GWP refrigerants as a direct substitute to $\mathrm{R} 134 \mathrm{a}$ in a domestic refrigerator. They concluded that R1234yf could be used as a natural substitute to R134a. Mohammad Hasheer Sk et al. [16] performed a thermodynamic analysis of low gwp refrigerant mixtures as alternative to $\mathrm{R} 134 \mathrm{a}$ in refrigerator. From that they concluded that R290/600(60/40), ARM42, ARM42a, R440A, and R430A have better COP execution and volumetric cooling limit than
$\mathrm{R} 134 \mathrm{a}$, which makes it the best substitute to R134a shows a favorable conditions.

A review of existing literature shows that much research has been done to find suitable alternative refrigerants from different groups individually. But the combination of two or more refrigerants from $\mathrm{HC}, \mathrm{HFC}$ and $\mathrm{HFO}$ groups have not tried so far by the previous researchers. Also, the performance evaluation with LSHX was not done extensively. So the present work mainly focuses on filling that research gap. So the investigation was carried out with the refrigerants AC5, R440A and R430A. They are the combination of two or more refrigerants from the above-said groups. So the performance of a domestic refrigerator involving LSHX was evaluated with these three refrigerants, and the best alternative refrigerant to replace R134a have been identified and suggested.

\section{ENVIRONMENTAL IMPACT OF ALTERNATIVE REFRIGERANT MIXTURES}

Low GWP refrigerants can be categorized as pure Hydrofluorocarbons and Hydrofluoroolefins. Hydrofluoroolefins (HFO) is not new to chemistry. Like conventional Hydrofluorocarbons (HFCs), they are composed of hydrogen, fluorine and carbon. The only difference is that they are unsaturated, which means they have at least one double bond. Such molecules are called olefins or alkenes, so it is correct to name refrigerants such as HFC, HFA or HFO. The next name has become the most used name to refer to carbon-carbon double-bond refrigerants. Hydrofluoroolefins can be classified as HFO-1225, 1234 and 1243 isomers. Due to the flammability, the R1243 isomer is not used, and also, due to toxicity, the HFO-1225 isomer has not been developed. Therefore, the two possible alternatives in a household refrigeration system are HFO-1234yf and 1234ze (E). Another low GWP refrigerant is pure Hydrofluorocarbons, i.e. HFC152a, which has a very low GWP, value compared with HFC134a. HC (Hydrocarbons) are natural refrigerants that are R290 and R600a. These refrigerants have a GWP value of zero and exceptional properties in terms of efficiency and cooling effect.

The alternative refrigerants require not only protecting the ozone layer but also a lower GWP value. The low GWP refrigerants mixtures are R440A (R290/R134a/R152a in the ratio of $0.6: 1.6: 97.8$ by mass, respectively), $\mathrm{R} 430 \mathrm{~A}$ (R152a/R600a 76:24in the ratio, by mass) and AC5 (R32/R152a/R1234ze (E) 12:5:83 in the ratio, by mass) were proposed in this document considered as substitutes for HFC134a. The Thermo-physical and Environmental properties of above refrigerants are mentioned in the Table 1.

Table 1. Thermo-physical and Environmental properties of the refrigerants investigated

\begin{tabular}{|c|c|c|c|c|}
\hline \multirow[t]{3}{*}{ Properties } & \multicolumn{4}{|c|}{ Refrigerants } \\
\hline & R134a & AC5 & R440A & R430A \\
\hline & & $\mathrm{R} 32(12 \%)$ & R290 (0.6\%) & $\mathrm{R} 152 \mathrm{a}(76 \%)$ \\
\hline Composition & ----- & $\mathrm{R} 152 \mathrm{a}(5 \%)$ & R134a (1.6\%) & R600a $(24 \%)$ \\
\hline & & R1234ze (E) $(83 \%)$ & $\mathrm{R} 152 \mathrm{a}(97.8 \%)$ & \\
\hline Molar mass (kg/kmol) & 102 & 96.7 & 66.23 & 63.96 \\
\hline Critical temperature $\left({ }^{\circ} \mathrm{C}\right)$ & 101.01 & 103.2 & 112.66 & 106.98 \\
\hline Boiling point, $\mathrm{BP}\left({ }^{\circ} \mathrm{C}\right)$ & -26.1 & -34.3 to -23.3 & -25.4 & -27.6 \\
\hline Liquid density at $298 \mathrm{~K}\left(\mathrm{~kg} / \mathrm{m}^{3}\right)$ & 1206.7 & 1101.2 & 897.62 & 759.78 \\
\hline Vapor densityat $298 \mathrm{~K}\left(\mathrm{~kg} / \mathrm{m}^{3}\right)$ & 32.35 & 28.92 & 18.68 & 19.69 \\
\hline ODP & 0 & 0 & 0 & 0 \\
\hline GWP & 1430 & 92 & 150 & 104 \\
\hline
\end{tabular}


GWP value of the refrigerant mixtures can be calculated as follows:

$$
G W P_{\text {mixture }}=G W P_{p} x W_{p}+G W P_{q} x W_{q}+G W P_{r} x W_{r}
$$

where, GWPp=GWP value of refrigerants $p, G W P q=G W P$ value of refrigerant $q, G W P r=G W P$ value of refrigerant $r$ respectively; $\mathrm{Wp}, \mathrm{Wq}$ and $\mathrm{Wr}$ are to be mass fraction of refrigerants $\mathrm{p}, \mathrm{q}$ and $\mathrm{r}$.

\section{THERMODYNAMIC REFRIGERANT MIXTURES}

ANALYSIS

OF

The thermodynamic Analysis of AC5, R440A and R430Aas a direct substitute to HFC-134a in a refrigeration system by varying the working conditions, i.e. when changing the temperature of the evaporator from $-200^{\circ} \mathrm{C}$ to $100^{\circ} \mathrm{C}$ at different condenser temperatures. The complete analysis has been carried out by using an internal heat exchanger.

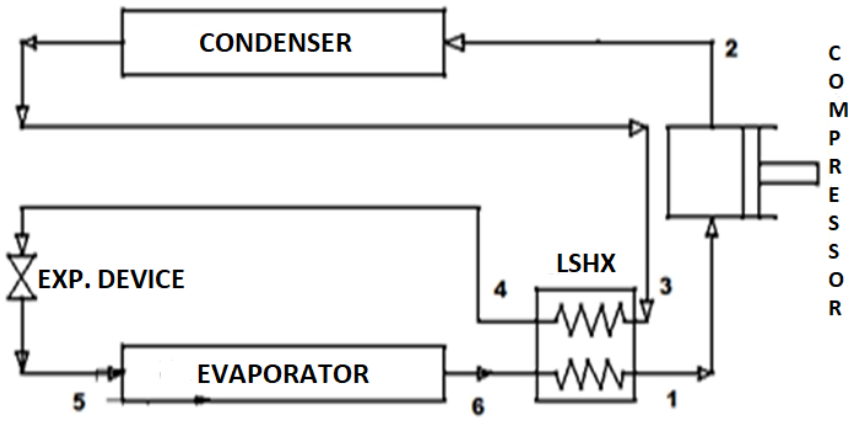

Figure 1. Refrigerator with LSHX

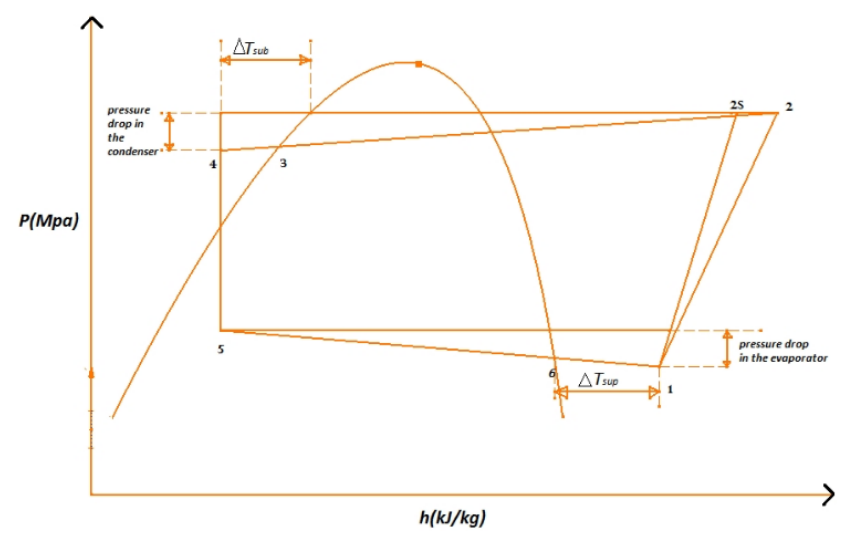

Figure 2. Pressure-enthalpy diagram of a refrigerator with LSHX

Data (from the literature review) used for analysis are given below. The results are plotted as shown in Figures 3 to 8 .

1. Condensing temperatures: $40^{\circ} \mathrm{C}$ and $50^{\circ} \mathrm{C}$

2. Evaporating temperatures: $-20^{\circ} \mathrm{C}$ to $10^{\circ} \mathrm{C}$

3. Loss of Pressure in the evaporator: $0.03 \mathrm{MPa}$

4. Loss of Pressure in the condenser: $0.02 \mathrm{MPa}$

5. Isentropic efficiency of a compressor: 0.70

6. Volumetric efficiency: 0.75

7. Compressor had a swept volume: $8.16 \mathrm{~cm}^{3} / \mathrm{rev}$

8. Compressor Speed: 30rev/sec

9. Effectiveness of the heat exchanger: 0.6.
The components of a domestic refrigerator with LSHX in the position shown in Figure 1. The pressure-enthalpy diagram with the heat exchanger is shown in Figure 2. At the entry to the compressor, the refrigerant is in superheated condition, and pressure losses are considered. At the same time, it passes through the evaporator and condenser and is also represented in Figure 2. REFPROP 9.1 software is used to calculate the properties at each state, which is very accurate software for calculating properties.

Pressure ratio, volumetric cooling capacity, COP, outlet compressor temperature, Refrigeration effect and compressor power consumption is the main parameters to accept a direct substitute to a domestic refrigerator.

\subsection{Performance parameters}

The pressure ratio can be expressed as

$$
r_{p}=P_{\text {cond }} / P_{\text {evap_act }}
$$

Compressor power consumption can be calculated from

$$
\dot{\mathrm{W}}_{\text {comp }} \quad \dot{\mathrm{m}}_{\mathrm{r}}\left(\mathrm{h}_{2}-\mathrm{h}_{1}\right) \mathrm{kW}
$$

Here $h_{1} \& h_{2}$ are the enthalpies of the refrigerant at entry and exit of the compressor. The relation between these two can be obtained by defining isentropic efficiency $\left(\eta_{\text {isen }}\right)$ of the compressor as follows

$$
\text { Where } h_{2}=h_{1}+\left(h_{2 s}-h_{1}\right) / \eta_{\text {isen }}
$$

The refrigeration effect of a refrigerator can be calculated by

Refrigeration effect, $Q_{r}=\left(h_{1}-h_{5}\right) \quad \mathrm{kJ} / \mathrm{kg}$

Here $h_{5}$ is the enthalpy of the refrigerant at the entry to the evaporator.

The cooling capacity of a refrigerator can be calculated by

$$
\begin{gathered}
\text { Cooling Capacity, } \dot{Q}_{c}=\dot{m}_{r} Q_{r}=\dot{m}_{r}\left(h_{1}-\right. \\
\left.h_{5}\right) k W
\end{gathered}
$$

The Coefficient of Performance (COP) of the refrigerator is given by

$$
\begin{aligned}
\text { COP } & =\frac{\text { Cooling capacity }}{\text { Compressor power consumption }} \\
& =\frac{\dot{m}_{r}\left(h_{1}-h_{5}\right)}{\dot{m}_{r}\left(h_{2}-h_{1}\right)}=\frac{\left(h_{1}-h_{5}\right)}{\left(h_{2}-h_{1}\right)}
\end{aligned}
$$

The Volumetric Cooling Capacity (VCC) is given by

$$
Q_{\text {vol }}=\left(h_{1}-h_{5}\right) \times \eta_{v o l} / v_{1} \mathrm{~kJ} /
$$

Here $\eta_{v o l}$ is the volumetric efficiency of the compressor and $v_{1}$ is the specific volume of the refrigerant at the compressor inlet.

The mass flow rate of the refrigerant $\left(\dot{m}_{r}\right)$ is given by

$$
\dot{m}_{r}=V_{s} \times \rho_{1} \times R P M \times \eta_{v o l} / 60 \mathrm{~kg} / \mathrm{s}
$$




\section{RESULTS AND DISCUSSION}

In the present work the performance of domestic refrigerator incorporated with LSHX was tested with different refrigerants AC5, R440A and R430A at two condenser temperatures of $40^{\circ} \mathrm{C}$ and $50^{\circ} \mathrm{C}$ with varying evaporator temperature from $-20^{\circ} \mathrm{C}$ to $10^{\circ} \mathrm{C}$. The results obtained from the theoretical analysis were mentioned in the Appendix and the important performance plots are drawn and discussed as below.

\subsection{Variation of the mass flow rate of alternative refrigerants}

Figure 3 depicts the mass flow rate of four refrigerants versus the temperature of the evaporator. Mass flow rate is the mass of refrigerant which pass per unit time. Mass flow rate is directly proportional to vapour density. Mass flow rate changes with change in evaporator temperature and do not vary with condenser temperature. For AC5, the mass flow rate is lower than $\mathrm{R} 134 \mathrm{a}$ by $8.59 \%$ within an evaporator temperature range of $-20^{\circ} \mathrm{C}$ to $10^{\circ} \mathrm{C}$, respectively. For R440a, the mass flow rate is lower than HFC-134a by $30.18 \%$ within an evaporator temperature range of $-20^{\circ} \mathrm{C}$ to $10^{\circ} \mathrm{C}$, respectively. For R430a, the mass flow rate is lower than HFC134 a by $25.75 \%$ within an evaporator temperature range of $20^{\circ} \mathrm{C}$ to $10^{\circ} \mathrm{C}$, respectively, due to low vapour density. Hence we can expect low power consumption with the above refrigerants as compared to R134a.

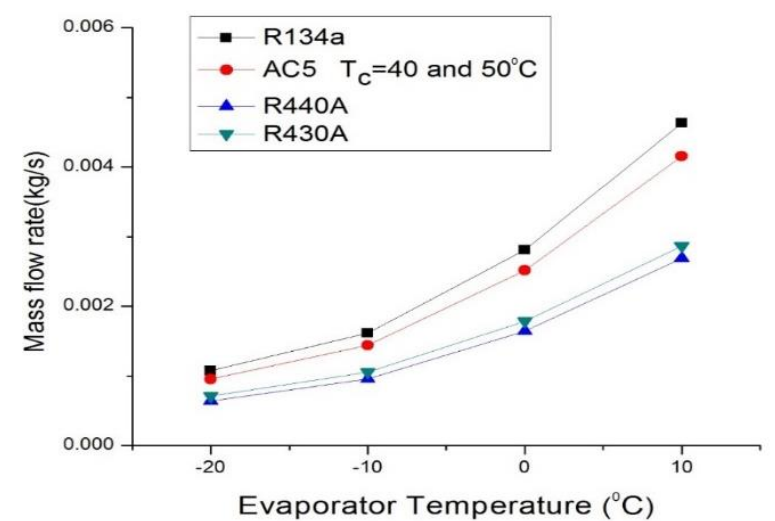

Figure 3. Refrigerant Mass flow rate (Kg/s) vs. Evaporator temperature $\left({ }^{\circ} \mathrm{C}\right)$

\subsection{Pressure ratio variation}

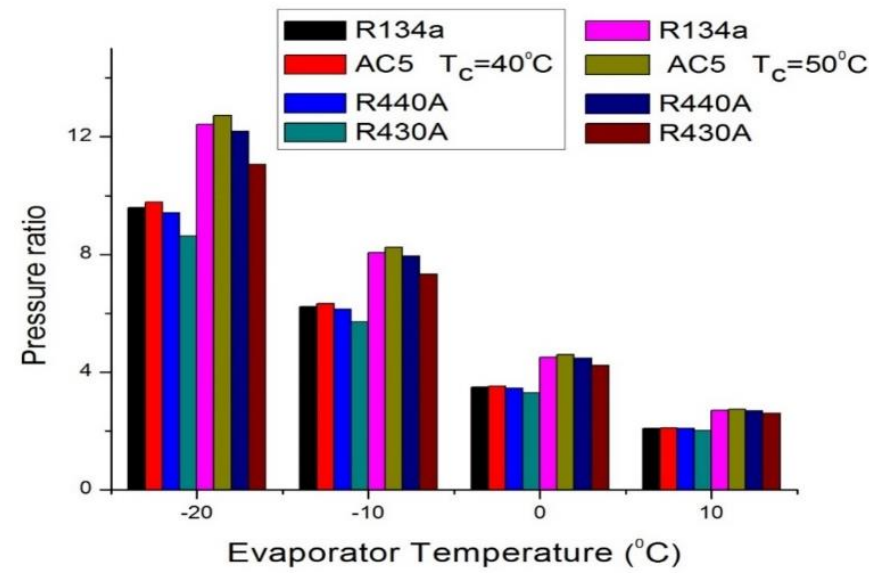

Figure 4. Pressure ratio vs Evaporator temperature $\left({ }^{\circ} \mathrm{C}\right)$
Figure 4 shows the graph between pressure ratios versus evaporator temperature. Pressure ratio is a ratio of higher pressure to lower pressure in VCR (vapour compression system). The pressure ratio is directly proportional to condenser temperature and inversely proportional to evaporator temperature. The results show that the pressure ratio of AC5 was higher than that of HFC-134a by approximately $1.13 \%, 1.48 \%$, and $1.88 \%$. At the same time, the pressure ratio of $\mathrm{R} 440 \mathrm{~A}$ and $\mathrm{R} 430 \mathrm{~A}$ lower than that of R134a by about $1.19 \%, 5.78 \%$, respectively. Compressor volumetric efficiency compressor is influenced by pressure ratio. It is inversely proportional to volumetric efficiency, so from the above results, we observed that R440A and R430A have some percentage drop in pressure ratio compared to R134a. So we can expect excellent volumetric efficiency with these refrigerants.

\subsection{Variation of volumetric cooling capacity}

Figure 5 describes the deviation of VCC concerning the evaporator temperature for four different refrigerants. At a condenser temperature of $40^{\circ} \mathrm{C}$ and $50^{\circ} \mathrm{C}$, it was obtained that the VCC of AC5 is lower than R134a by $9.91 \%, 10.10 \%$ and $10.35 \%$, respectively, within an evaporator temperature range of $-20^{\circ} \mathrm{C}$ to $10^{\circ} \mathrm{C}$, respectively. VCC of R440A is lower than $\mathrm{R} 134 \mathrm{a}$ by $6.4 \%, 5.1 \%$, and $3.4 \%$, respectively, within an evaporator temperature range of $-20^{\circ} \mathrm{C}$ to $10^{\circ} \mathrm{C}$. At $40^{\circ} \mathrm{C}$ and $50^{\circ} \mathrm{C}$ of condenser temperatures, R430a has a VCC lower than $\mathrm{R} 134 \mathrm{a}$ by $1.12 \%, 0.41 \%$, and higher by $0.44 \%$, respectively, within an evaporator temperature range $20^{\circ} \mathrm{C}$ and $10^{\circ} \mathrm{C}$. The capacity of volumetric cooling has a more significant influence on the size of the compressor. For replacement refrigerants, VCC can be maintained with a limit between $-8 \%$ and $8 \%$ about HFC-134a. Due to a lower volumetric cooling capacity, AC5 Refrigerant is not advisable as it affects the compressor performance. Therefore, this refrigerant cannot be replaced as an alternative to HFC-134a. Consequently, considering that refrigerants $\mathrm{R} 440 \mathrm{~A}, \mathrm{R} 430 \mathrm{~A}$ are suggested as a direct replacement of HFC-134a without alterations in the compressor.

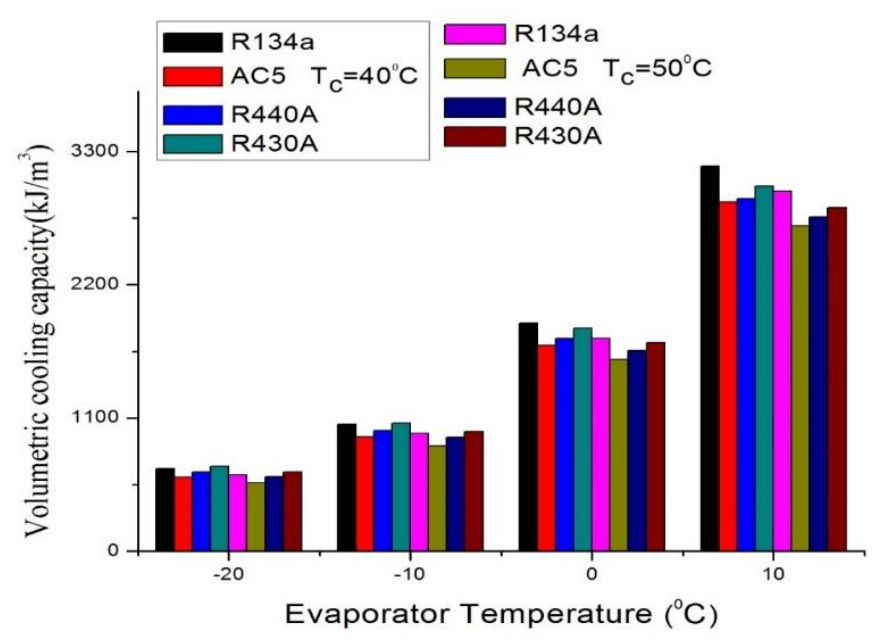

Figure 5. VCC vs Evaporator temperature $\left({ }^{\circ} \mathrm{C}\right)$

\subsection{Variation of compressor power}

The variation of compressor power versus evaporator temperature is shown in Figure 6. The average compressor 
power consumption of refrigerants AC5, R440a, R430a was lower than that of HFC-134a by about $4.1 \%, 7.6 \%$ and $1.4 \%$ respectively at condenser temperatures $40^{\circ} \mathrm{C} \& 50^{\circ} \mathrm{C}$. The energy consumption of a refrigerator compressor increases with the evaporator temperature due to the increase in the enthalpy difference between the output and the compressor inlet. This difference in enthalpy is due to the rise in the mass flow rate of the refrigerant.

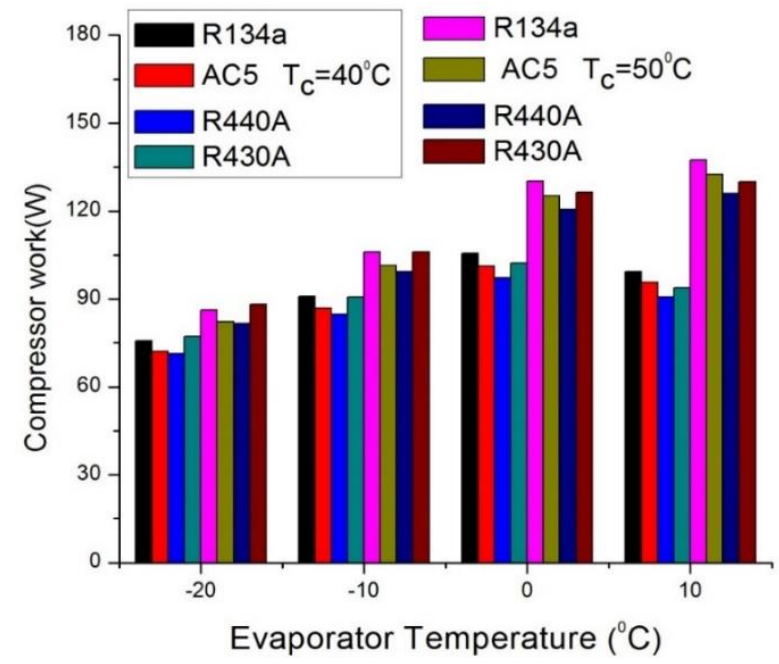

Figure 6. Compressor work (W) vs Evaporator temperature $\left({ }^{\circ} \mathrm{C}\right)$

\subsection{Variation of COP}

Figure 7 represents the deviation of COP of alternative refrigerants versus evaporator temperature. It was obtained that the average COP of R440A, R430A was higher than HFC$134 \mathrm{a}$ by approximately $1.37 \%, 2.7 \%$ at a condenser temperature $40 \mathrm{C}$ and higher than that of R134a $2.5 \%, 3.2 \%$, respectively at a condenser temperature of $50^{\circ} \mathrm{C}$. This is due to the lower power consumption of a refrigerator compressor. On the other hand, AC5 has a lower cop than R134a by approximately $6.58 \%, 5.6 \%$ at a condenser temperature of $40^{\circ} \mathrm{C}$ and $50^{\circ} \mathrm{C}$.

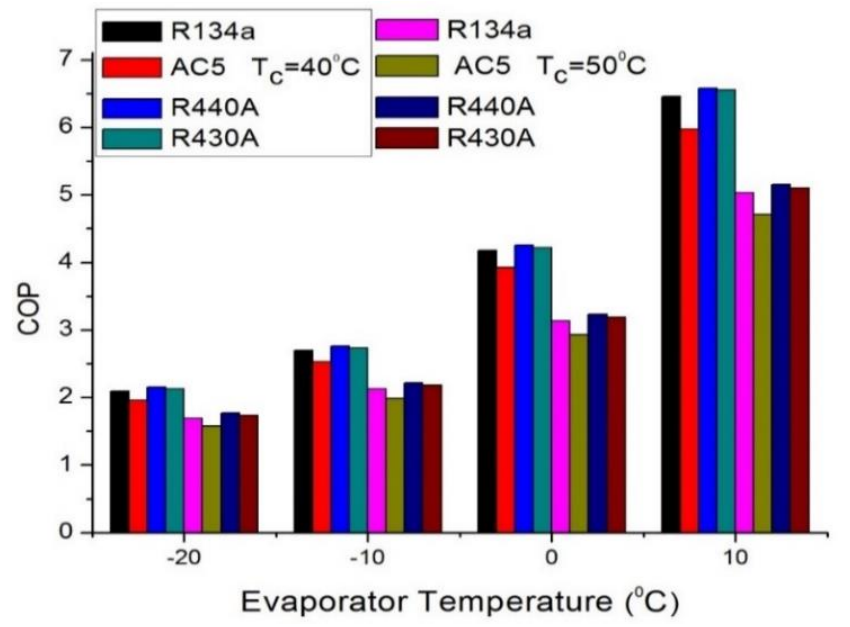

Figure 7. COP vs. Evaporator temperature $\left({ }^{\circ} \mathrm{C}\right)$

\subsection{Variation of outlet temperature of compressor}

The outlet temperature of the reciprocating refrigerant compressor versus evaporator temperature is shown in Figure 8 below. It was found that the average discharge temperature of compressor AC5, R440A and R430A was higher than that of HFC-134a of approximately $6-10^{\circ} \mathrm{C}, 3-7^{\circ} \mathrm{C}$ and $2-6^{\circ} \mathrm{C}$ at condenser temperatures of $40^{\circ} \mathrm{C} \& 50^{\circ} \mathrm{C}$. The higher outlet temperature affects the compressor motor coil and also affect the lubricant oil properties. Therefore, care must be taken when using this refrigerant as a direct substitute to HFC-134a in a refrigerator.

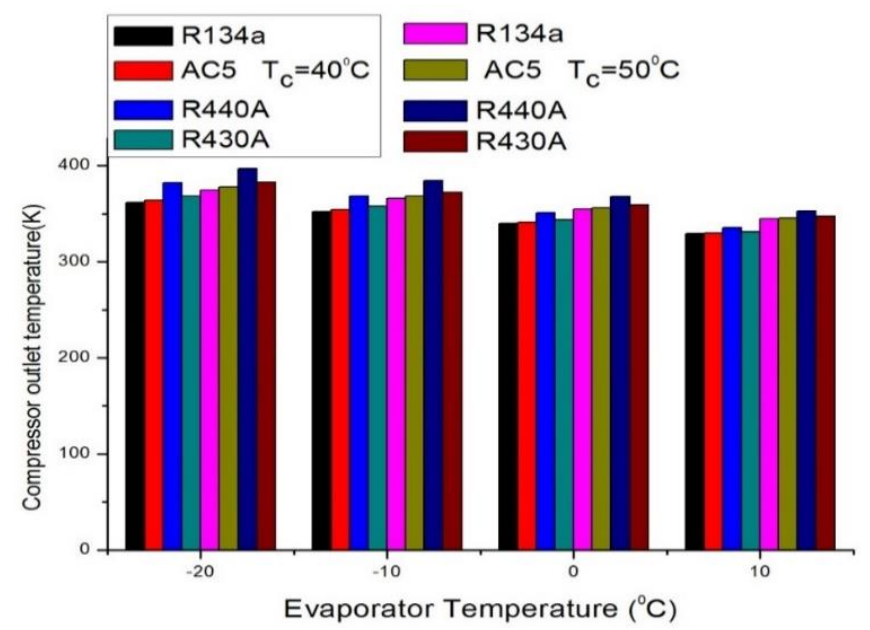

Figure 8. Compressor outlet temperature $(\mathrm{K})$ vs. Evaporator temperature $\left({ }^{\circ} \mathrm{C}\right)$

\section{CONCLUSIONS}

The AC5 refrigerant shows a much lower volumetric cooling capacity compared to HFC-134a of approximately $9.1 \%$. For a direct replacement, the value must be between $-8 \%$ and $8 \%$. Therefore, it is not suitable for direct use as a substitute for HFC-134a in a household refrigerator. R440A and R430A had given good results in VCC, power consumption of a compressor, $\mathrm{COP}$ and pressure ratio. But R440A shows a high compressor output temperature that affects the properties of lubricating oil for refrigerator compressor. When comparing all results with R134a, R430A can be used as a direct substitute for HFC-134a in the household refrigerator without changing the refrigerator. Therefore, it is concluded that R430A can be used as an alternative to HFC-134a in a household refrigerator. At the same time, when comparing the results with the literature (without LSHX) there is an improvement in the performance of a household refrigerator.

\section{REFERENCES}

[1] Bolaji, B.O. (2014). Theoretical analysis of the energy performance of three low global warming potential hydro-fluorocarbon refrigerants as R134a alternatives in refrigeration systems. Proceedings of the Institution of Mechanical Engineers, Part A: Journal of Power and Energy, 228(1): 56-63. https://doi.org/10.1177\%2F0957650913507252

[2] Jung, D., Chong-Bo, K., Kilhong, S., Byoungjin, P. (2000). Testing of propane/Isobutene mixture in domestic refrigerators. International Journal of 
Refrigeration,

23:

$517-527$

https://doi.org/10.1016/S0140-7007(99)00084-5

[3] Fatouh, M., Kafafy, M.E. (2006). Experimental evaluation of a refrigerator working with LPG. Applied Thermal Engineering, 26: 1593-1603. https://doi.org/10.1016/j.applthermaleng.2005.11.026

[4] Garland, N.P., Hadfield, M. (2005). Environmental implications of hydrocarbon refrigerants applied to hermetic compressor. Material and Design Journal, 26(7): 578-586. https://doi.org/10.1016/j.matdes.2004.08.009

[5] Dalkilic, A.S., Wongwises, S. (2010). A performance comparison of vapour compression refrigeration system using various alternative refrigerants. International Communication in Heat and Mass Transfer, 37(9): 13401349.

https://doi.org/10.1016/j.icheatmasstransfer.2010.07.00 6

[6] Naushad, A.A., Yadav, B., Kumar, J. (2013). Theoretical Exergy analysis of HFP-1234yf and HFO-1234ze as an alternative replacement of HFC134a in simple vapour compression refrigeration system. International Journal of Scientific \& Engineering Research, 4(8): 2229-5518.

[7] Rasti, M., Aghamiri, S.F., Hatamipour, M.S. (2013). Energy efficiency enhancement of a domestic refrigerator using R436A and R600a as alternative refrigerants to R134a. International Journal of Thermal Sciences, 74:

86-94. https://doi.org/10.1016/j.ijthermalsci.2013.07.009

[8] Joybari, M.M., Hatamipour, M.S., Rahimin, A. (2013). Exergy analysis and optimization of R600a as a replacement of R134a in a domestic refrigeration system. International Journal of refrigeration, 36(4): 1233-1242. 2013. https://doi.org/10.1016/j.ijrefrig.2013.02.012

[9] Bilen, K., Kalkisim, A.T., Solmus, I. (2014). The performance of alternative refrigerant gas R152a as mobile air conditioning refrigerant. Chemical Engineering, 39: 1801-1806. https://doi.org/10.3303/CET1439301

[10] Bolaji, B.O., Huan, Z.J., Borokinni, F.O. (2014). Energy performance of Eco-friendly R152a and R600a refrigerants as alternative to $\mathrm{R} 134 \mathrm{a}$ in vapour compression refrigeration system. Analele Universităłii "Eftimie Murgu" Reşiła Anul., XXI, NR. 1.

[11] Morsi, M.E. (2015). Energy and exergy analysis of LPG (liquefied petroleum gas) as a drop in replacement for R134a in domestic refrigerators. Energy, 86: 344-353. https://doi.org/10.1016/j.energy.2015.04.035

[12] Meng, Z., Zhang, H., Qiu, J., Lei, M. (2016). Theoretical analysis of R1234ze(E), R152 and R1234ze(E)/R152a mixtures as replacements of R134a in vapor compression system. Advances in Mechanical Engineering, 8(11): 344-353. https://doi.org/10.1177/1687814016676945

[13] Sánchez, D., Cabello, R., Llopis, R., Arauzo, I., CatalánGil, J., Torrella, E. (2017). Energy performance evaluation of R1234yf, R1234ze(E), R600a, R290 and $\mathrm{R} 152 \mathrm{a}$ as low-GWP R134a alternatives. International
Journal of Refrigeration, 74: 269-282. https://doi.org/10.1016/j.ijrefrig.2016.09.020

[14] Makhnatch, P., Mota-Babiloni, A., Khodabandeh, R. (2017). Experimental study of R450A drop-in performance in an R134a small capacity refrigeration. International Journal of Refrigeration, 84: 26-35. https://doi.org/10.1016/j.ijrefrig.2017.08.010

[15] Hasheer Sk, M., Srinivas, K. (2018). Theoretical analysis of low global warming potential refrigerant as a drop in replacement of R134a in a domestic refrigerator. Iranian Journal of Energy and Environment, 9(2): 130-136. https://doi.org/10.5829/IJEE.2018.09.02.08

\section{NOMENCLATURE}

$\begin{array}{ll}\text { COP } & \text { Coefficient of performance } \\ \text { GWP } & \text { Global warming potential } \\ \mathrm{h} & \text { Specific enthalpy }(\mathrm{kJ} / \mathrm{kg}) \\ \mathrm{LSHX} & \text { Liquid - suction heat exchanger } \\ \dot{m} & \text { Mass flow rate }(\mathrm{kg} / \mathrm{s}) \\ \text { Qvol } & \text { Volumetric Cooling Capacity }\left(\mathrm{kJ} / \mathrm{m}^{3}\right) \\ \dot{Q}_{c} & \text { Cooling capacity }(\mathrm{kW}) \\ \mathrm{Q} r & \text { Refrigeration effect }(\mathrm{kJ} / \mathrm{kg}) \\ \mathrm{R} & \text { Refrigerant } \\ \mathrm{rp} & \text { pressure ratio } \\ \mathrm{v} & \text { Specific volume }\left(\mathrm{m}^{3} / \mathrm{kg}\right) \\ \mathrm{Vs} & \text { Compressor displacement }\left(\mathrm{m}^{3} / \mathrm{rev}\right) \\ \dot{W}_{\text {Comp }} & \text { Compressor power consumption }(\mathrm{kW})\end{array}$

Greek symbols

$\begin{array}{ll}\eta & \text { Efficiency }(\%) \\ \rho & \text { Density }\left(\mathrm{kg} / \mathrm{m}^{3}\right)\end{array}$

\section{Subscripts}

1, 2, 3,4,5,6
Comp
Cond
evap_act
isen
Lshx
r
vol

state points compressor condenser actual evaporator isentropic liquid suction heat exchanger refrigerant volumetric

\section{Acronym}

$\begin{array}{ll}\text { CFC } & \text { Chlorofluorocarbons } \\ \text { HC } & \text { Hydrocarbons } \\ \text { HCFC } & \text { Hydrochlorofluorocarbons } \\ \text { HFC } & \text { Hydrofluorocarbons } \\ \text { HFO } & \text { Hydrofluoroolefins } \\ \text { RPM } & \text { Revolutions per minute }\end{array}$


Theoretical results of different refrigerants investigated

\begin{tabular}{|c|c|c|c|c|c|}
\hline \multicolumn{6}{|c|}{ CONDENSER TEMP $=20^{\circ} \mathrm{C}$} \\
\hline Evaporator Temp $\left({ }^{\circ} \mathrm{C}\right)$ & Parameter & $\mathrm{R} 134 \mathrm{a}$ & $\mathrm{AC} 5$ & $\mathrm{R} 440 \mathrm{a}$ & $\mathrm{R} 430 \mathrm{a}$ \\
\hline \multirow[t]{7}{*}{-20} & $\mathrm{COP}$ & 2.723 & 2.5521 & 2.7922 & 2.7582 \\
\hline & $\mathrm{T} 2$ & 330.065 & 331.480 & 347.223 & 336.074 \\
\hline & $\operatorname{Pr}$ & 7.2566 & 7.3811 & 7.1322 & 6.6142 \\
\hline & $\mathrm{RE}$ & 163.995 & 146.565 & 158.465 & 169.485 \\
\hline & $\mathrm{W}$ & 60.2248 & 57.4273 & 56.7522 & 61.4463 \\
\hline & $\mathrm{mr}$ & 0.00107 & 0.00095 & 0.00063 & 0.00071 \\
\hline & Qvol & 669.914 & 598.716 & 647.328 & 692.343 \\
\hline \multirow[t]{7}{*}{-10} & $\mathrm{COP}$ & 3.625 & 3.4029 & 3.6927 & 3.6619 \\
\hline & $\mathrm{T} 2$ & 324.551 & 325.613 & 337.831 & 329.122 \\
\hline & $\mathrm{Pr}$ & 4.7068 & 4.7726 & 4.6501 & 4.3807 \\
\hline & $\mathrm{RE}$ & 257.224 & 230.958 & 244.255 & 259.090 \\
\hline & $\mathrm{W}$ & 70.9565 & 67.8699 & 66.144 & 70.7525 \\
\hline & $\mathrm{mr}$ & 0.00161 & 0.00144 & 0.00095 & 0.00105 \\
\hline & Qvol & 1050.75 & 943.456 & 997.774 & 1058.37 \\
\hline \multirow[t]{7}{*}{0} & COP & 6.129 & 5.7709 & 6.1894 & 6.1697 \\
\hline & $\mathrm{T} 2$ & 317.8262 & 318.4168 & 326.0162 & 320.5626 \\
\hline & $\mathrm{Pr}$ & 2.6333 & 2.6578 & 2.6164 & 2.5197 \\
\hline & $\mathrm{RE}$ & 474.2585 & 428.4571 & 439.8774 & 461.4826 \\
\hline & $\mathrm{W}$ & 77.3791 & 74.2438 & 71.0685 & 74.7971 \\
\hline & $\mathrm{mr}$ & 0.00281 & 0.002516 & 0.001646 & 0.001781 \\
\hline & Qvol & 1937.33 & 1750.233 & 1796.885 & 1885.141 \\
\hline \multirow[t]{7}{*}{10} & $\mathrm{COP}$ & 13.7203 & 12.941 & 13.7439 & 13.7623 \\
\hline & $\mathrm{T} 2$ & 312.4305 & 312.6931 & 316.2469 & 313.6699 \\
\hline & $\mathrm{Pr}$ & 1.5778 & 1.5853 & 1.57375 & 1.546 \\
\hline & $\mathrm{RE}$ & 822.2744 & 746.8862 & 746.5463 & 776.1278 \\
\hline & W & 59.9311 & 57.71468 & 54.3182 & 56.395 \\
\hline & $\mathrm{mr}$ & 0.004631 & 0.004154 & 0.00269 & 0.002862 \\
\hline & Qvol & 3358.964 & 3051.006 & 3049.617 & 3170.457 \\
\hline \multicolumn{6}{|c|}{ CONDENSER TEMP $=40^{\circ} \mathrm{C}$} \\
\hline Evaporator Temp $\left({ }^{\circ} \mathrm{C}\right)$ & Parameter & $\mathrm{R} 134 \mathrm{a}$ & $\mathrm{AC} 5$ & $\mathrm{R} 440 \mathrm{a}$ & $\mathrm{R} 430 \mathrm{a}$ \\
\hline \multirow[t]{7}{*}{-20} & $\mathrm{COP}$ & 2.1509 & 2.007329 & 2.2407 & 2.1958 \\
\hline & $\mathrm{T} 2$ & 341.38 & 343.0975 & 360.4962 & 348.0223 \\
\hline & $\operatorname{Pr}$ & 9.5808 & 9.7791 & 9.4043 & 8.6289 \\
\hline & $\mathrm{RE}$ & 148.5438 & 132.3568 & 146.8354 & 155.2198 \\
\hline & $\mathrm{W}$ & 69.05949 & 65.9367 & 65.5297 & 70.6885 \\
\hline & $\mathrm{mr}$ & 0.001071 & 0.000954 & 0.000637 & 0.000713 \\
\hline & Qvol & 606.7968 & 540.6732 & 599.8181 & 634.0681 \\
\hline \multirow[t]{7}{*}{-10} & $\mathrm{COP}$ & 2.7832 & 2.602066 & 2.8737 & 2.8298 \\
\hline & $\mathrm{T} 2$ & 336.1375 & 337.4736 & 351.4524 & 341.3648 \\
\hline & $\operatorname{Pr}$ & 6.2143 & 6.32313 & 6.1314 & 5.7151 \\
\hline & $\mathrm{RE}$ & 233.9562 & 209.5158 & 226.8553 & 238.0492 \\
\hline & $\mathrm{W}$ & 84.0598 & 80.519 & 78.9397 & 84.1203 \\
\hline & $\mathrm{mr}$ & 0.001613 & 0.00144 & 0.000953 & 0.001052 \\
\hline & Qvol & 955.7038 & 855.8653 & 926.6964 & 972.4235 \\
\hline \multirow[t]{7}{*}{0} & $\mathrm{COP}$ & 4.3449 & 4.0743 & 4.4332 & 4.3937 \\
\hline & $\mathrm{T} 2$ & 329.7558 & 330.5883 & 340.0767 & 333.1769 \\
\hline & $\mathrm{Pr}$ & 3.4767 & 3.52137 & 3.4499 & 3.2872 \\
\hline & $\mathrm{RE}$ & 433.7212 & 391.0004 & 409.8254 & 425.8386 \\
\hline & $\mathrm{W}$ & 99.822 & 95.9665 & 92.4435 & 96.9192 \\
\hline & $\mathrm{mr}$ & 0.00281 & 0.002516 & 0.001646 & 0.001781 \\
\hline & Qvol & 1771.737 & 1597.224 & 1674.124 & 1739.537 \\
\hline \multirow[t]{7}{*}{10} & $\mathrm{COP}$ & 7.8321 & 7.3536 & 7.9006 & 7.8727 \\
\hline & $\mathrm{T} 2$ & 324.648 & 325.1269 & 330.6743 & 326.595 \\
\hline & $\mathrm{Pr}$ & 2.0832 & 2.1004 & 2.075 & 2.0169 \\
\hline & $\mathrm{RE}$ & 755.4909 & 685.0454 & 697.4433 & 718.862 \\
\hline & W & 96.46 & 93.15769 & 88.2767 & 91.3104 \\
\hline & $\mathrm{mr}$ & 0.004631 & 0.004154 & 0.00269 & 0.002862 \\
\hline & Qvol & 3086.156 & 2798.388 & 2849.033 & 2936.528 \\
\hline \multicolumn{6}{|c|}{ CONDENSER TEMP $=50^{\circ} \mathrm{C}$} \\
\hline Evaporator Temp $\left({ }^{\circ} \mathrm{C}\right)$ & Parameter & $\mathrm{R} 134 \mathrm{a}$ & AC5 & R440a & R430a \\
\hline \multirow[t]{2}{*}{-20} & $\mathrm{COP}$ & 1.7149 & 1.5916 & 1.8266 & 1.7702 \\
\hline & $\mathrm{T} 2$ & 352.0495 & 354.1167 & 372.6777 & 359.1741 \\
\hline
\end{tabular}




\begin{tabular}{|c|c|c|c|c|c|}
\hline & Pr & 12.4233 & 12.7302 & 12.1808 & 11.0684 \\
\hline & RE & 132.6201 & 117.6973 & 134.8612 & 140.4975 \\
\hline & W & 77.3331 & 73.948 & 73.8288 & 79.3646 \\
\hline & $\mathrm{mr}$ & 0.001071 & 0.000954 & 0.000637 & 0.000713 \\
\hline & Qvol & 541.749 & 480.7898 & 550.9037 & 573.9278 \\
\hline & COP & 2.1799 & 2.02766 & 2.2951 & 2.238 \\
\hline & T2 & 347.1343 & 348.7888 & 364.0624 & 352.8692 \\
\hline & Pr & 8.058 & 8.2313 & 7.9417 & 7.3309 \\
\hline & RE & 209.977 & 187.3936 & 208.9412 & 216.3344 \\
\hline & W & 96.321 & 92.4182 & 91.034 & 96.6602 \\
\hline & mr & 0.001613 & 0.00144 & 0.000953 & 0.001051 \\
\hline & Qvol & 857.7492 & 765.4971 & 853.518 & 883.7192 \\
\hline & COP & 3.2445 & 3.02757 & 3.3638 & 3.3068 \\
\hline & T2 & 341.162 & 342.2775 & 353.226 & 345.1232 \\
\hline & Pr & 4.5082 & 4.584 & 4.4685 & 4.2165 \\
\hline & RE & 391.9443 & 352.356 & 378.8852 & 389.0541 \\
\hline & W & 120.8016 & 116.3821 & 112.6342 & 117.6506 \\
\hline & $\mathrm{mr}$ & 0.00281 & 0.002516 & 0.001646 & 0.001781 \\
\hline & Qvol & 1601.08 & 1439.363 & 1547.734 & 1589.274 \\
\hline & COP & 5.2585 & 4.9131 & 5.3759 & 5.3205 \\
\hline & T2 & 336.3926 & 337.1259 & 344.271 & 338.9059 \\
\hline & Pr & 2.7012 & 2.7342 & 2.6877 & 2.5872 \\
\hline & RE & 686.6651 & 621.2437 & 646.889 & 659.7641 \\
\hline & W & 130.5816 & 126.4446 & 120.3311 & 124.0035 \\
\hline & $\mathrm{mr}$ & 0.004631 & 0.004154 & 0.00269 & 0.002862 \\
\hline & Qvol & 2805.005 & 2537.76 & 2642.521 & 2695.115 \\
\hline & & & & & \\
\hline & & & & \\
\hline & & & & \\
\hline & & &
\end{tabular}

